\title{
Biochemical differences between the virgin queens and workers of the Ant, Camponotus maculatus (Fabricius)
}

\section{Laila Sayed Hamouda}

Department of Entomology, Faculty of Science, Ain Shams Univ., Cairo, Egypt.

ABSTRACT

The present data showed that the activities of all the tested enzymes except acetylcholinesterase ( $\alpha, \beta$-esterases, acid phosphatase and glutathione S-transeferase) were significantly higher in the whole body homogenates of the virgin queens ant, Camponotus maculatus (Fabricius) than that recorded for the workers. Also, the concentration of total soluble proteins of the virgin queens was higher than of workers. These proteins were electrophoretically separated into 22 bands (258.6 to $35.4 \mathrm{KDa})$ in the virgin queen samples while they were separated into 19 bands $(216.7$ to $35.4 \mathrm{KDa}$ ) in the worker samples. Ten protein bands were common between the two castes $(108.1,103.9,99.8,94.6,63.7,61.3,55.9,48.1,40.6$ and $35.4 \mathrm{KDa})$ and the remaining bands were characteristic for each caste.Finally, there was difference in the genomic DNA of the two studied castes.

Key words: Differentiation - Queen - Worker - Enzymes - SDS Electrophoresis -DNAAnts

\section{INTRODUCTION}

Ants are social insects of the family Formicidae and, along with the related families of wasps and bees, belong to the order Hymenoptera. The highly organized colonies and nests of ants consist of millions of individuals. They are mostly sterile females (workers, soldiers, and other castes) with some fertile males (drones) and one or more fertile females (queens).Ants dominate most ecosystems, forming $15-20 \%$ of the terrestrial animal biomass. Their success has been attributed to their social structure, ability to modify their habitats, tap resources and defend themselves (AntWikipedia ,the free encyclopedia).

Acetylcholinesterase is an enzyme that catalyzes the hydrolysis of neurotransmitter acetylcholine into choline and acetic acid .It has the potential for serving both as biochemical indicator of toxic stress and is also used a biomarker for heavy metal pollution (Sharaawi et al.,2002).

Esterases are enzymes involved in several important physiological processes in organisms, including reproduction, digestion, metabolism of juvenile hormone and detoxification of xenobiotics (Perez-Mendoza et al., 2002 and Shanmugavelu et al., 2000).

Acid phosphatase is important in biological processes that need high level of energy, such as development, growth, gamete's maturation and histolysis(Ray et al., 1984). The selection of this enzyme as an indicator of sterility is based on it's importance in the reproductive system in insects (Moore and Frazier, 1976).

The primary function of glutathione S-transferase is generally considered to be the detoxification of both endogenous and xenobiotic compounds (Wilce and Parker, 1994). 
Polyacrylamide gel electrophoresis has been used for separation of protein in different castes of honey bee (Chan et al., 2006).

A PCR based technique known as random amplified polymorphic DNA (RAPD) does not require knowledge of specific sequences, but rather uses random 10 base-pair primers. This method has become very useful for identification and differentiation of closely related insect species and populations (Williams et al., 1990).

The present work aimed to determine the biochemical differences between the virgin queens and workers of Camponotus maculatus (Fabricius) from Egypt through studying the activities of some of their vital enzymes (acetylcholinesterase, $\alpha, \beta-$ esterases, acid phosphatase and glutathione S- transferase). The concentration of their total soluble proteins was also measured. Moreover, their electrophoretic protein patterns and genomic DNA were studied.

\section{MATERIALS AND METHODS}

The virgin queens and workers of Camponotus maculatus were supplied by Prof. Dr. Reda Fadeel who collected them from $6^{\text {th }}$ October governorate. These samples were homogenized in distilled water using a Teflon homogenizer surrounded with a jacket of crushed ice for 3 minutes. Homogenates were centrifuged at 6000 r.p.m. for 10 minutes, and the supernatants were used directly for determination of total soluble proteins and enzyme assays.

\section{Biochemical study}

\section{Enzyme assays:}

- The activity of acetylcholinesterase (AChE) was assayed colorimetrically according to the method described by Simpson et al. (1964). Acetylcholine bromide (AchBr) was used as a substrate.

- The activity of the enzyme was expressed as $\mu \mathrm{g}$ substrate hydrolyzed / $\mathrm{min} / \mathrm{g}$ body weight.

- The activities of $\alpha$ and $\beta$-esterases were determined according to the method of Van Asperen (1962) using $\alpha$-naphthyl acetate and $\beta$-naphthyl acetate as substrates, respectively. Naphthol produced as a result of substrate hydrolysis can be measured by the addition of diazoblue sodium lauryl sulphate solution which produces a strong blue colour in case of $\alpha$-naphthol or strong red colour in the case of $\beta$-naphthol. The colour was measured spectrophotometrically (by Milton Roy Spectronic model 1201 spectrophotometer).

- The activity of the enzyme was expressed as $\mu \mathrm{g} \alpha$ - or $\beta$-naphthol released /min. / g body weight.

- Acid phosphatase (AcP) activity was measured according to the method described by Powell and Smith (1954). In this method, the phenol released by enzymatic hydrolysis of disodium phenylphosphate, reacts with 4aminoantipyrine, and by the addition of potassium ferricyanide, the characteristic brown colour is produced.

The produced color was measured immediately by spectrophotometer at $510 \mathrm{~nm}$. The enzymatic activity is expressed as $\mu \mathrm{g}$ phenol released $/ \mathrm{min} / \mathrm{g}$ body weight.

Glutatione S-transferase activity (GST) was assayed in the presence of 1,2Dichloro-nitrobenzen as a substrate according to the method of Habig et al., (1974).

A unit of activity is defined as the amount of enzyme catalyzing the formation of $1 \mu$ mole of product per min. 
The concentration of total soluble proteins was determined in whole body homogenates of virgin queens and workers according to the method of Bradford (1976).

\section{Statistical analysis}

The significance in variation of enzyme activities means of queens and workers was assayed according to Smith (2004).

\section{Protein Electrophoresis}

Sodium dodecyl sulphate polyacrylamide gel electrophoresis (SDS-PAGE) was used for separation of proteins of queens and workers according to Laemmli (1970).

Protein samples of whole body of virgin queens and workers $(20 \mu \mathrm{g})$ were loaded together with Bio RAD molecular markers (208-37 Kda). The gel was stained by Coomasie blue followed by immersion in a destaining solution. The destained gel was photographed and quantitative analysis of protein patterns was done using a laser densitometer and a computerized Gel Document system.

\section{Extraction and PCR amplification of genomic DNA}

DNA was extracted from virgin queens and workers according to the manufacturer specifications of genomic DNA isolation kit of (Promega ,USA). The extracted DNA was then used as an amplification template for RAPD-PCR analysis, using 10 primers (OPH-03, OPH-02, OPH-09, OPG-17, OPB-10, OPB-03, OPF-09, OPG-06, OPG-04, and OPC-02).

The total reaction volume was $50 \mu 1$ containing 100 ng DNA. 50 pmol primer, $200 \mu \mathrm{M} \mathrm{DNTP}{ }_{4}$ (dATP, dGTP, dCTA, \& dTTP), $3 \mathrm{mM} \mathrm{MgCl}_{2}$, and $0.5 \mathrm{Tag}$ polymerase. Amplification was performed using DNA thermal cycler (Perkin Elmer Cetus, model 2400). The thermal conditions were as follows: $6 \mathrm{~min}$. at $94^{\circ} \mathrm{C}$ (hot start), 40 cycles $\left(1 \mathrm{~min}\right.$. at $94^{\circ} \mathrm{C}, 2 \mathrm{~min}$. at $36^{\circ} \mathrm{C}, \& 3 \mathrm{~min}$. at $\left.72^{\circ} \mathrm{C}\right)$, and a final extension (post extension) of $10 \mathrm{~min}$. at $72^{\circ} \mathrm{C}$. The PCR products were run out on $1.8 \%$ agarose gels and then stained with ethidium bromide. Separation was documented by photography, using Polaroid ${ }^{\mathrm{R}}$ camera. The values of DNA fragment sizes (bps) as well as those of the DNA markers were automatically computerized.

\section{Sequences of primers:}

\begin{tabular}{ll}
\hline OPH-03 & 5'-AGACGTCCAC-3' \\
OPH-02 & 5'-TCGGACGTGA-3' \\
OPH-09 & 5'-TGTAGCTGGG-3' \\
OPG-17 & 5'-ACGACCGACA-3' \\
OPB-10 & 5' -CTGCTGGGAC-3 ' \\
OPB-03 & 5'-CATCCCCCTG-3' \\
OPF-09 & 5'-CCAAGCTTCC-3' \\
OPG-06 & 5'- GTGCCTAACC-3' \\
OPG-04 & 5'-AGCGTGTCTG-3' \\
OPC-02 & 5'-GTGAGGCGTC-3'
\end{tabular}

\section{RESULTS AND DISCUSSION}

\section{Enzyme assays:}

The activities of acetylcholinesterase, $\alpha, \beta$-esterases, acid phosphatase and glutathione S-transferase in the whole body homogenates of the virgin queens and workers ant, Camponotus maculatus have been studied. 


\section{Acetylcholinesterase:}

It is well known that acetylcholinesterase (AChE) is the target site for organophosphorus and carbamate insecticides. Thus, the increase in its activity as shown in Table (1) might be required by the workers to maintain the colony and this may reflect the toxic stress that face the ants from application of insecticides used for control. This explanation was supported by Umit and Halil (2000) who stated that the activity of $\mathrm{AChE}$ in the resistant strain of Anopheles sacharovi collected from localities which receive intensive insecticides was higher than that collected from localities where insecticides are used in small quantity or not used at all.

\section{$\alpha$ and $\beta$-esterases:}

The activities of $\alpha$ - and $\beta$-esterases in the virgin queens were significantly higher than that detected for the workers. The activities were $797 \pm 58.1 \mu \mathrm{g} \alpha$ naphthol $/ \mathrm{g} / \mathrm{min}$. and $862.2 \pm 102.6 \mu \mathrm{g} \beta$ - naphthol $/ \mathrm{g} / \mathrm{min}$. for the virgin queens compared with $32.1 \pm 4$. $7 \mu \mathrm{g} \alpha$-naphthol $/ \mathrm{g} / \mathrm{min}$ and $25.7 \pm 3.5 \mu \mathrm{g} \beta$-naphthol $/ \mathrm{g} / \mathrm{min}$. for the workers, respectively (Table 1) These enzymes are involved in insecticide degradation, their increased activity being the main mechanism in organophosphorus resistance, in several organisms (Vaughan and Hemingway, 1995; Vaughan et al., 1997). Thus, it could be suggested that queens produced high levels of esterases to minimize the effect of toxic materials (insecticides).i.e to become more resistant to organophosphorus insectsides as reported by Lima Catelani, (1996) and Sousa-Polezzi (2002) who found an increase in the synthesis of some esterases in A. aegypti resistant to organophosphorus insectisides.

\section{Acid phosphatase:}

Results in Table (1) revealed a significant higher activity of acid phosphatase $(\mathrm{AcP})$ in the virgin queen samples than that detected for the workers. The activity was $9.9 \pm 1.6 \mu \mathrm{g}$ phenol $/ \mathrm{g} / \mathrm{min}$. for the virgin queen samples compared with $1.8 \pm 0.3 \mu \mathrm{g}$ $\mathrm{phenol} / \mathrm{g} / \mathrm{min}$. for the worker samples.

Table 1: The activities of acetylcholinesterase (AChE), $\alpha, \beta$ - esterases acid phosphatase (AcP) glutathaione $\mathrm{S}$ - transferase and the concentration of total proteins of virgin queens and workers ant, Camponotus maculatus.

\begin{tabular}{|c|c|c|c|c|}
\hline \multirow{2}{*}{ Parameter } & \multicolumn{2}{|c|}{ Mean $\mathbf{S D}$} & \multirow{2}{*}{ F $_{\mathbf{1 , 4}}$} & \multirow{2}{*}{ Significance } \\
\cline { 2 - 3 } & Worker & Virgin Queen & \multirow{2}{*}{} \\
\hline Acetylcholinesterase & $1376.6 \pm 215.1$ & $1128.5 \pm 126.4$ & 2.97 & Not Sign. \\
\hline$\alpha$ - Esterase & $32.1 \pm 4.7$ & $797 \pm 58.1$ & 517.45 & $1 \%$ \\
\hline$\beta$ - Esterase & $25.7 \pm 3.5$ & $862.2 \pm 102.6$ & 199.25 & $1 \%$ \\
\hline Acid phosphatase & $1.8 \pm 0.3$ & $9.9 \pm 1.6$ & 76.20 & $1 \%$ \\
\hline Glutathione S- transferase & $1.64 \pm 0.3$ & $58.9 \pm 7.2$ & 187.43 & $1 \%$ \\
\hline Total soluble Proteins & $13.1 \pm 2.1$ & $43.7 \pm 14.1$ & 13.92 & $5 \%$ \\
\hline
\end{tabular}

Enzymes activities were expressed as follows:

The activity of AChE was expressed as $\mu \mathrm{g} \mathrm{ACh} \mathrm{Br} / \mathrm{gm} / \mathrm{min}$.

The activity of $\alpha$ and $\beta$-esterases were expressed as $\mu \mathrm{g} \alpha$ or $\beta$ naphthol $/ \mathrm{min} . / \mathrm{gm}$ body weight .

The activity of AcP was expressed as $\mu \mathrm{g}$ phenol / $\mathrm{min}$. /gm body weight.

The activity of glutathaione $\mathrm{S}$-transferase was expressed as $\mathrm{M}$ of product/min.

The concentration of total soluble proteins was expressed as $\mathrm{mg} / \mathrm{g}$ body weight.

This result agrees with that reported by El Sherif et al., ( 1990) who found a highest level of AcP. in the reproductive caste of termites while the soldiers and workers exhibited lower levels of activity. These results may be attributed to the importance of AcP in reproducing individuals (Moore and Frazier, 1976) .Moreover,the enzyme enhances the addition of phosphate ions to the phosphate pool for synthesis of high energy needed to gamete's maturation (Bogitsh ,1974) and DNA 
synthesis (Moore \& Fraizer, 1976). On the other hand, the lowest level of AcP activity observed in workers and soldiers of termites are explained by being sterile castes.

\section{Glutathione S-transferase:}

The activity of glutathione S-transferase (GST) of the virgin queens was significantly higher than that detected for workers (Table 1). The activity of the GST enzyme was $58.9 \pm 7.2 \mathrm{M}$ product/min for virgin queens while it was $1.64 \pm 0.3 \mathrm{M}$ product/min for the workers.

GST could be considered an important component of the defense of herbivorous insects against both exogenous and endogenous oxidative radicals as reported by (Krishnan and Nodrik, 2006). Therefore, lack of glutathione has been shown to leave the body more vulnerable to damage. Thus, virgin queens produced high amount of this enzyme to protect their bodies from wearing by these free radicals..Moreover,GST enzyme has a significant role in the detoxification of organophosphorus and pyrethroid insecticides (Hooper-Bùi et al., 2005) .Thus, the higher level of the activity of this enzyme recorded in the virgin queens in the present study might be a prerequisite for the queens to defend themselves against the above mentioned insecticides. This explanation may be supported by Umit and Halil (2000) who found that the activity of GST enzyme was higher in Anopheles sacharovi collected from localities receiving intensive insecticide application than in localities where insecticides are used in smaller quantities or not at all.

\section{Total soluble proteins}

Table (1) shows that the concentration of total soluble proteins detected from the whole body homogenates of virgin queens was higher than that detected from the workers. It was $43.7 \pm 14.1 \mathrm{mg} / \mathrm{gbody}$ weight compared to $13.1 \pm 2.1 \mathrm{mg} / \mathrm{g}$ body weight.

Wilkinson (1976) stated that proteins help insects to synthesis microsomal detoxifying enzymes. Therefore, the decrease in the concentration of total proteins detected from the whole body homogenates of worker samples in the present study may reflect the decrease in activity of these enzymes that may lead to their death from application of insecticides. Proteins also involved in the defense against reactive oxygen substance (ROS) have major effects on longevity in many if not all organisms (Nystrom, 2005, Finkel and Holbrook, 2000). Therefore, the presence of high concentration of proteins in the virgin queens protect them from these substances to maintain their life.

It has been reported that lack of sufficient ROS defense mechanisms in foraging bees reflects reduced somatic maintenance. This effect was directly and positively linked to the circulating vitellogenin protein levels in the bees. Vitellogenin was shown to exhibit characteristic antioxidant function being preferentially carbonylated by ROS (Wolschin and Amdam, 2007)

Finally, the detected high concentration of total soluble proteins in the virgin queen samples in the present study may be explained as mentioned by Hahn et al., (2004) who stated that the storage protein content has evolved by the queens of harvester ant of genus Pogonomyrmex in concert with colony -founding strategies

Protein Electrophoresis:

Electrophoretic fractionation of the whole body homogenates of the virgin queen samples revealed the presence of 22 protein bands with molecular weights ranged from 258.6 to $35.4 \mathrm{KDa}$. While there were 19 protein bands ranged from 216.7 to $35.4 \mathrm{KDa}$ in the worker samples. Ten of these bands $(108.1,103.9,99.8,94.6,63.7$, $61.3,55.9,48.1,40.6$ and $35.4 \mathrm{KDa}$ ) were common between the aforementioned two castes of $C$. maculatus. The remaining bands were characteristics for each caste. They were twelve in the virgin queens samples $(258.6,228.8,210.9,189.1,154.1$, 
$140.1,101.4,82.4,66.3,53.4,42.3$ and $38.7 \mathrm{KDa})$. While they were nine for the worker samples (216.7, 208,191.7 ,162.8, 138.3, 89.1, 86.2, 68.1 and 57.8 KDa) ( Table 2 and Fig. 1 (A) \& (B)).

Chan et al., (2006) also found differences in electrophoretic separation of haemolymph proteins between workers and queens of Apis mellifera.

Myles and Change (1984) studied the differences in electrophoretic protein profiles in all castes of the termite, Neotermes connexus. They attributed their results to cuticular pigmentation and sclerotization which in nymphs markedly differ from reproduction castes.

Table (2): Relative molecular weights of different protein bands detected in the whole body homogenates of the virgin queens (q) and workers (w) of Camponotus maculatus.

\begin{tabular}{|c|c|c|c|}
\hline Band no. & Molecular Weights (KDa) & Virgin queens & Workers \\
\hline 1 & 258.6 & 1 & 0 \\
\hline 2 & 228.8 & 1 & 0 \\
\hline 3 & 216.7 & 0 & 1 \\
\hline 4 & 210.9 & 1 & 0 \\
\hline 5 & 208 & 0 & 1 \\
\hline 6 & 191.7 & 0 & 1 \\
\hline 7 & 189.1 & 1 & 0 \\
\hline 8 & 162.8 & 0 & 1 \\
\hline 9 & 154.1 & 1 & 0 \\
\hline 10 & 140.1 & 1 & 0 \\
\hline 11 & 138.3 & 0 & 1 \\
\hline 12 & 108.1 & 1 & $1 *$ \\
\hline 13 & 103.9 & 1 & $1 *$ \\
\hline 14 & 101.4 & 1 & 0 \\
\hline 15 & 99.8 & 1 & $1 *$ \\
\hline 16 & 94.6 & 1 & $1 *$ \\
\hline 17 & 89.1 & 0 & 1 \\
\hline 18 & 86.2 & 0 & 1 \\
\hline 19 & 82.4 & 1 & 0 \\
\hline 20 & 68.1 & 0 & 1 \\
\hline 21 & 66.3 & 1 & 0 \\
\hline 22 & 63.7 & 1 & $1^{*}$ \\
\hline 23 & 61.3 & 1 & $1 *$ \\
\hline 24 & 57.8 & 0 & 1 \\
\hline 25 & 55.9 & 1 & $1 *$ \\
\hline 26 & 53.4 & 1 & 0 \\
\hline 27 & 48.1 & 1 & $1 *$ \\
\hline 28 & 42.3 & 1 & 0 \\
\hline 29 & 40.6 & 1 & $1 *$ \\
\hline 30 & 38.7 & 1 & 0 \\
\hline 31 & 35.4 & 1 & $1 *$ \\
\hline Total brand & & 22 & 19 \\
\hline
\end{tabular}

(*) means common protein bands between the virgin queens and workers of ant, Camponotus maculatus.

\section{RAPD-PCR analysis:}

The results recorded in Table 3 and illustrated in Figs. (2, $3 \& 4$ ) reveal distinguishable differences in Genomic DNA between the virgin queens and workers of Camponotus maculatus.

Distinct DNA fragments that amplified by the tested primers are referred to as RAPD markers. They are considered to be queen specific if they were found only in the virgin queen samples as shown in Table (3) under the column with symbol (1). Likewise, markers are considered to be worker specific if found only in worker samples as shown in Table (3) under the column with symbol (2). 
Table 3:DNA profile of virgin queen ( 1 ) and worker ( 2 ) of Camponotus maculatus using RAPDPCR technique and OPH-03, OPH-02, OPH-09 and OPG-17 primers

\begin{tabular}{|c|c|c|c|c|c|c|c|c|c|}
\hline & \multicolumn{9}{|c|}{ Primers } \\
\hline \multirow{2}{*}{$\begin{array}{l}\text { Band } \\
\text { No. }\end{array}$} & \multirow{2}{*}{$\begin{array}{c}\text { Approx. band } \\
\text { size in bp }\end{array}$} & \multicolumn{2}{|c|}{ ОРН-03 } & \multicolumn{2}{|c|}{ ОРН-02 } & \multicolumn{2}{|c|}{ ОРН-09 } & \multicolumn{2}{|c|}{ OPG-17 } \\
\hline & & (1) & (2) & (1) & (2) & (1) & (2) & (1) & (2) \\
\hline 1 & 1839 & & & & & 1 & 0 & & \\
\hline 2 & 1491 & & & 1 & 0 & 0 & 1 & 1 & 0 \\
\hline 3 & 1415 & & & & & 1 & 0 & & \\
\hline 4 & 1148 & & & & & 1 & 0 & & \\
\hline 5 & 981 & 1 & 0 & & & & & 0 & 1 \\
\hline 6 & 931 & & & 1 & 0 & & & 1 & 0 \\
\hline 7 & 893 & & & & & 1 & 0 & & \\
\hline 8 & 756 & 0 & 1 & & & 0 & 1 & & \\
\hline 9 & 717 & & & 0 & 1 & & & 0 & 1 \\
\hline 10 & 681 & & & 1 & 0 & & & 0 & 1 \\
\hline 11 & 613 & 1 & 0 & & & & & 1 & 1 \\
\hline 12 & 524 & & & & & & & 0 & 1 \\
\hline 13 & 497 & 1 & 0 & & & & & & \\
\hline 14 & 472 & & & & & & & 1 & 0 \\
\hline 15 & 448 & 0 & 1 & & & & & & \\
\hline 16 & 425 & 1 & 0 & & & & & & \\
\hline 17 & 363 & & & & & 1 & 0 & & \\
\hline 18 & 327 & & & & & 0 & 1 & & \\
\hline 19 & 295 & & & & & & & 0 & 1 \\
\hline 20 & 280 & 1 & 0 & & & 1 & 0 & & \\
\hline 21 & 252 & & & & & & & 0 & 1 \\
\hline 22 & 227 & 1 & 0 & & & 1 & 0 & & \\
\hline
\end{tabular}

Table 3 Cont.: DNA profile of virgin queen ( 1 ) and worker ( 2 ) of Camponotus maculatus using RAPD- PCR technique and OPB-10, OPB-03, OPF-09 and OPG-06 primers 


\begin{tabular}{|c|c|c|c|c|c|c|c|c|c|}
\hline & \multicolumn{9}{|c|}{ Primers } \\
\hline Band & $\begin{array}{c}\text { Approx. } \\
\text { band size in } \\
\text { No. }\end{array}$ & \multicolumn{2}{|c|}{ OPB-10 } & \multicolumn{2}{c|}{ OPB-03 } & \multicolumn{2}{|c|}{ OPF-09 } & \multicolumn{2}{|c|}{ OPG-06 } \\
\hline & bp & (1) & (2) & (1) & (2) & (1) & (2) & (1) & (2) \\
\hline 1 & 1936 & & & & & 1 & 0 & & \\
\hline 2 & 1838 & & & 1 & 0 & & & & \\
\hline 3 & 1744 & & & & & 0 & 1 & & \\
\hline 4 & 1491 & 0 & 1 & & & & & & \\
\hline 5 & 1343 & & & 1 & 0 & & & & \\
\hline 6 & 1274 & 0 & 1 & & & & & & \\
\hline 7 & 1210 & & & & & & & 0 & 1 \\
\hline 8 & 1148 & & & & & 0 & 1 & & \\
\hline 9 & 1034 & & & 1 & 1 & 1 & 0 & & \\
\hline 10 & 931 & 0 & 1 & & & & & 0 & 1 \\
\hline 11 & 884 & 0 & 1 & 1 & 0 & & & & \\
\hline 12 & 839 & & & & & & & 1 & 1 \\
\hline 13 & 796 & & & 0 & 1 & & & & \\
\hline 14 & 756 & 1 & 0 & & & & & & \\
\hline 15 & 717 & & & & & 1 & 0 & & \\
\hline 16 & 681 & 0 & 1 & & & & & 1 & 0 \\
\hline 17 & 613 & & & 1 & 0 & & & & \\
\hline 18 & 497 & & & & & 1 & 1 & & \\
\hline 19 & 383 & & & & & & & 0 & 1 \\
\hline
\end{tabular}


Table 3 Cont.: DNA profile of virgin queen ( 1 ) and worker ( 2 ) of Camponotus maculatus using RAPD- PCR technique and OPG-04, and OPC-02primers

\begin{tabular}{|c|c|c|c|c|c|}
\hline \multirow{3}{*}{$\begin{array}{l}\text { Band } \\
\text { No. }\end{array}$} & \multicolumn{5}{|c|}{ Primers } \\
\hline & \multirow{2}{*}{$\begin{array}{c}\text { Approx. band size in } \\
\text { bp }\end{array}$} & \multicolumn{2}{|c|}{ OPG-04 } & \multicolumn{2}{|c|}{ OPC-02 } \\
\hline & & (1) & (2) & (1) & (2) \\
\hline 1 & 756 & & & 1 & 0 \\
\hline 2 & 719 & & & 0 & 1 \\
\hline 3 & 704 & & & 1 & 0 \\
\hline 4 & 635 & 1 & 0 & & \\
\hline 5 & 609 & & & 1 & 0 \\
\hline 6 & 561 & 1 & 1 & & \\
\hline 7 & 527 & 0 & 1 & & \\
\hline 8 & 506 & 0 & 1 & 1 & 1 \\
\hline 9 & 497 & 1 & 0 & & \\
\hline 10 & 475 & & & 0 & 1 \\
\hline 11 & 465 & 0 & 1 & & \\
\hline 12 & 437 & & & 1 & 1 \\
\hline 13 & 411 & 1 & 1 & & \\
\hline 14 & 378 & & & 0 & 1 \\
\hline 15 & 341 & 0 & 1 & & \\
\hline 16 & 334 & & & 0 & 1 \\
\hline 17 & 314 & & & 0 & 1 \\
\hline 18 & 295 & 0 & 1 & 0 & 1 \\
\hline 19 & 280 & & & 1 & 0 \\
\hline 20 & 266 & & & 0 & 1 \\
\hline 21 & 245 & 1 & 1 & & \\
\hline
\end{tabular}

Out of 10 primers screened, 6 were found to reveal bands which were observed in the two studied castes. primer OPG-17 generated one band with $613 \mathrm{bp}$, primer OPB-03 generated one band with $1034 \mathrm{bp}$, primer OPF-09 generated one band with $497 \mathrm{bp}$, primer OPG-06 generated one band with 839bp, Primer OPG-04 
generated 3 bands (561, 411 and 245 bps), primer OPC-02 generated 2 bands (506 and $437 \mathrm{bps}$ ), (Table,3 and Figs. 2, 3 and 4).

The number of fragments (or loci) amplified with RAPD primers depends on factors such as the size, composition of the genome and the reaction conditions (Williams et al., 1990).

Polymorphisms generated with RAPD primers result from success or failure of the primer to bind, creating the presence or absence of a particular amplified band, and from insertions or deletions that change the length of the amplified region. In general most RAPD markers are of the first type and are dominant in expression, whereby a diploid with two copies of a RAPD marker cannot be distinguished from those containing one copy (Tingey et al., 1992 and Williams et al., 1990).

The observed difference in genomic DNA in the present study between the virgin queens and workers may be explained as the two studies castes resulted from hybridization between two colonies as reported by Julian et al., (2002) in the two seed harvester ants, Pogonomyrmex rugosus and Pogonomyrmex barfatus. They said that within area of sympatry of these two ant species, workers displayed bands that were absent in their alate queen sisters .The most parsimonious explanation for these genotype differences is that the workers and queens come from different patrilines. Because Hymenoptera are haplo-diploid, workers from the same father share the markers specific to that patriline. Males are produced parthenogenetically, and their genotypes reveal the queen's genotype. Therefore, markers absent in male but present in workers are inherited patrilinially.Moreover, the difference in genomic DNA between the two studies castes may be explained as mentioned by Fournier et al.,(2005) who stated that, in the little fire ant, Wasmannia auropunctata, female sexuals are produced by a meiotic parthenogenesis from unfertilized eggs, workers from fertilized eggs, and males from fertilized eggs after the elimination of the maternal nucleus, resulting in a complete separation of male and female gene pools.

In conclusion, since the numbers of queens in the ant's colony is one or few, the present study showed that the queens produce high levels of insecticide detoxifying enzymes ( $\alpha, \beta$-esterases, acid phosphatase and glutathione $S$ - transferase) as a mean of defensive mechanism against the insecticides that are used to control them .This study may also answer the question why insecticide treatment sometimes don't work .

Further molecular studies must be performed concerning expression of genes between the two castes to know the reliable cause of genetic difference between them.

\section{REFERENCES}

Bogitsh , B.J. (1974) : Acid phosphatase activity in spermatids of the snail, Biomphalaria glabrata . Trans. Am. Micros . Soc.93, 365-37.

Bradford, M. M. (1976): A rapid and sensitive method for the quantititaion of microgram quantitites of protein utilizing the principle of protein-dye binding. Anal. Biochem., 72: 248-254.

Chan, Q.W.T.; Howes, C.G. and Foster L.T. (2006): Quantitative comparison of cast differences in honey bee hemolymph. Mol. \& Cell. Proteomics; 5: 22522262.

EI. SHERIF, L.S.; Enan, R.A. and Radwan, W.A. (1990): Study of phosphatases and transaminases in relation to different castes of lower and higher termites. Proc. Int. Conf. St., comp. Sc. Soc. Res. and DEM. 
Finkel, T. and Holbrook, N.(2000): Oxidants, oxidative stress and the biology of ageing. Nature, 408: 239-247.

Fournier, D; Estoup, A; Orivel, J.; Le Bretonm J and Keller, L. (2005): Clonal reproduction by males and females in the little fire ant. Nature, 435: 12301234.

Habig, W. H.; Pabst, M. J. and Jakoby, W. B. (1974): Glutathione S-transferases: the first enzymatic step in mercapturic acid formation. J. Biol. Chem. 249(22): 7130-7139.

Hahn, D.A.; Johnson, R.A.; Buck, N.A. and Wheeler, D.E. (2004): Storage protein as a functional marker for colony-founding strategies: A comparative study within the harvester Ant Genus. Physiol. and Bioch. Zool. 77(1): 100-108.

Hooper- Bùi, L.M.; Zhisheng, J. and Jessica, L.R. (2005): Argentine ants, Linepithema humile. (Hymenopatera: Formicidae) in Louisiana: Ant-ant competition and treatment with insecticides. Proc. $5^{\text {th }}$ International conference on urban pests Chow-Yang lee and William H. Robinson (editors). Perniagaan Ph'ng(a) P\&Y Design Network, Malaysia.

Julian, G.E.; Jennifer, H.F.; Jürgen, G.; Robert, A. J. and Debbie, L. (2002): Genetic determination of the queen caste in ant hybrid zone. Proc. Natl. Acad. Sci. U.S.A. 99 (12): 8157-8160

Krishnan, N. and Nodrik, D. (2006): Antioxidant enzymes in Spodotera Littoralis (Boisduval): are they enhanced to protect gut tissues during oxidative strees? J. Insect Physiol., 52 (1): 11-20.

Laemmli, U.K. (1970). Cleavage of structural proteins during the assembly of the head of bacteriophage T4. Nature 227: 680-685.

Lima-Catelani, A.R.A. (1996): Padrão de esterases de Aedes aegyptie Aedes albopictus. PhD Thesis, Universidade Estadual Paulista, São, José de Rio Preto.

Moore, C. A. and Frazier, J.L. (1976): Partial characterization of acid phosphatases of the boll weevil, Anthonomus grandis. Insect Biochem., 6: 525-527.

Myles, T.G. and Change, F. (1984): The caste system and caste mechanisms of Neotermes cnnexus (Isoptera: Kalotermitidae). Sociobiol., 9: 316-321.

Nystrom, T. (2005): Role of oxidative carbonylation in protein quality control and senescence. J: Embryo. 24: 1311-1317.

Perez-Mendoza, J.; Fabrick, J.Á.; Zhu, K.Y. and Baker, J.E. (2002): Alterations in esterases are associated with malathion resistance in Hobrobracon hebetor (Hymenoptera: Braconidae). J Econ. Entomol 93: 31-37.

Powell , M.E.A. and Smith, M.J.H. (1954) : The determination of serum acid and alkaline phosphatases activity with 4-amino antipyrine. J. Clin. Pathol, $7: 245-248$.

Ray, A.; Rao, C.G.P.; Srivevi, R. and Ramamurty, P.S. (1984): Changes in acid phosphatase activity in Spodoptera litura (Lepi: Noctuidae) during the post embryonic and adult development . Entomol., 9(3): 161-167.

Shanmugavelu, M.; Baytan, A.R.; Chesnut, J.D.; and Bonning, B.C. (2000): A novel protein that binds juvenile hormone esterase in fat body tissue and pericardial cells of the tobacco horn worm, Manduca sexta L. J. Biol. Chem. 275: 1802-1806.

Sharaawi, F. A.; El Barmawy, S.M.; Abulyazid I.I. and Kamel, K.E. (2002): Enzymatic patterns through the different developmental stages of the red palm weevil, Rhynchophorus ferrugineus oliver (Coleoptera: Curculionidae) J. Egypt. Ger. Soc. Zool. Vol. (38E): Entomol.: 17-31. 
Simpson, D. R.; Bull, D. L. and Lindquist, D. A. (1964): A semimicro technique for the estimation of cholinesterase activity in boll weevil. Ann. Ent. Soc. Am ., 57 (3): 367-377.

Smith,G.(2004).Smith's statistical package version 2.75 .

Sousa-Polezzi, R.C. (2002): Resistência a insecticidas em Aedes aegypti modificaoes nos pardroes de esterases e acao dofenobarbital. PHD. Thesis ,universidade Estadual paulista,Sâo jóse do rio preto.

Tingey, S.V.; Rafalski, J.A. and Williams, J. G.K. (1992). Genetic analysis with RAPD markers. In: Proceedings of the symposium. Applications of RAPD Technology to Plant Breeding. Crop Science Society of America/ American Society of Horticultural Science/American Genetics Association: 3-8.

Umit, L. and Halil, K. (2000): Insecticide resistance in malaria vector Anopheles sacharovi Turkish. J. of Biology, 24 (3): 437-460.

Van Asperen, K. (1962): A study of housefly esterase by means of sensitive colourimetric method. J. Insect Physiol., 8: 401-416.

Vaughan, A. and Hemingway, J. (1995): Mosquito carboxylesterasc Est $\alpha 2^{1}\left(\mathrm{~A}_{2}\right)$ : cloning andsequence of the full-length cDNA for a major insecticide gene worldwide in the mosquito Culex quinquefasciatus. J Biol. chem. 270 (28): 1744-1749.

Vaughan, A.; Rocheleau, T. and FFrench-Constant, R. (1997): Site-directed mutagenesis of an acetylcholinesterase gene from the yellow fever mosquito Aedes aegypti confers insecticide insensitivity. Exp Parasitol 87: 237-244.

Wilce, M.C. and Parker, M.W. (1994): Structure and function of glutathione Stranferases. Biochim. Biophys. Acta, 1205: 1-18.

Wilkinson, F. (1976): Insecticide Biochemists and Physiology (Plenum Press, New York, ( U. S.A).

Williams, J.G.K; Kubellik, A. R.; Livak, K.J.; Rafalski, J.A. and Tingey, S.V. (1990): Nuclear Acids Res. 18: 6531-6535.

Wolschin, F. and Amdam, G.V. (2007). Comparative proteomics reveal characteristics of life history transitions in a social insect. Proteom. Scie.,5: 10. 


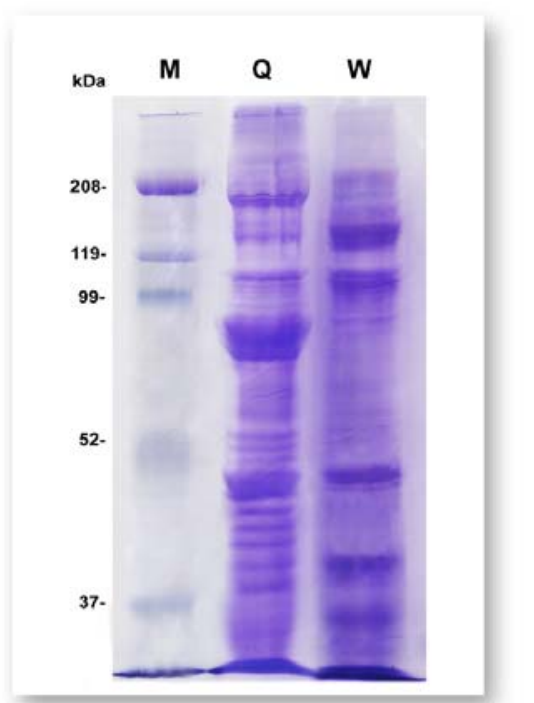

Fig. 1-(A)

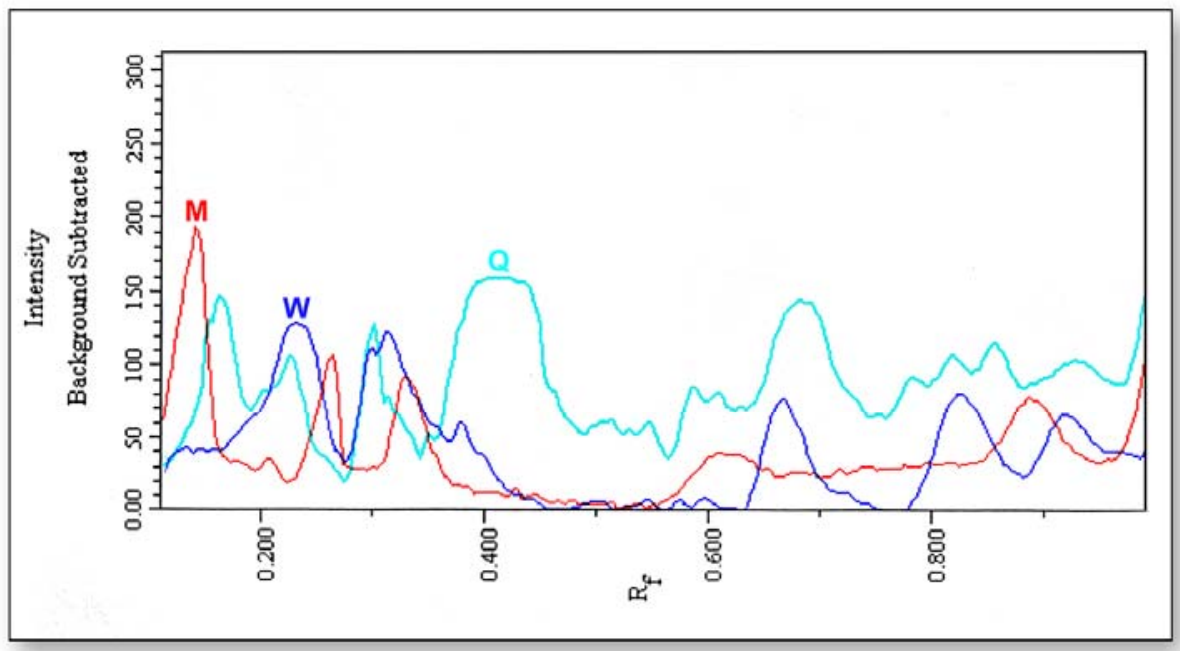

Fig. 1-(B)

Fig. 1: (A). The SDS PAGE gel showing the protein banding patterns of the virgin queens (q) and workers (w) of Camponotus maculatus.

(B). Densitometer tracing of the protein profiles for the above mentioned two castes. The results are computerized using the gel Documentation system (GDS). 


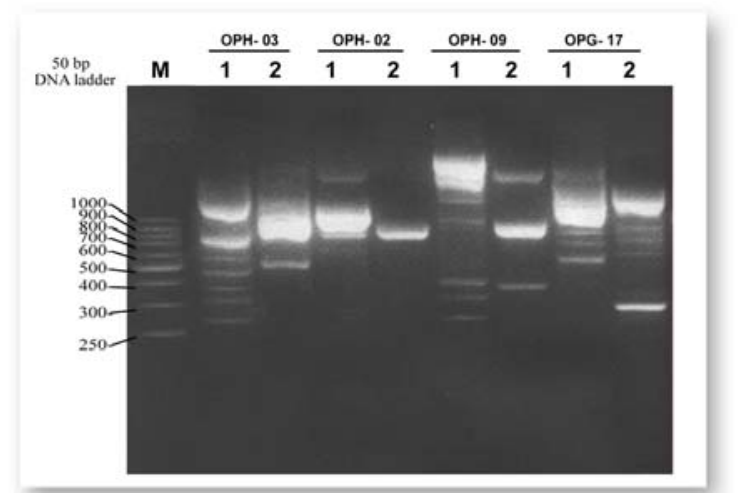

Fig. 2: Agrose - gel electrophoresis of genomic DNA of virgin queens (1) and workers (2) of Camponotus maculatus using RAPD-PCR technique and the primers OPH-03, OPH-02,OPH-9 and OPG-17.

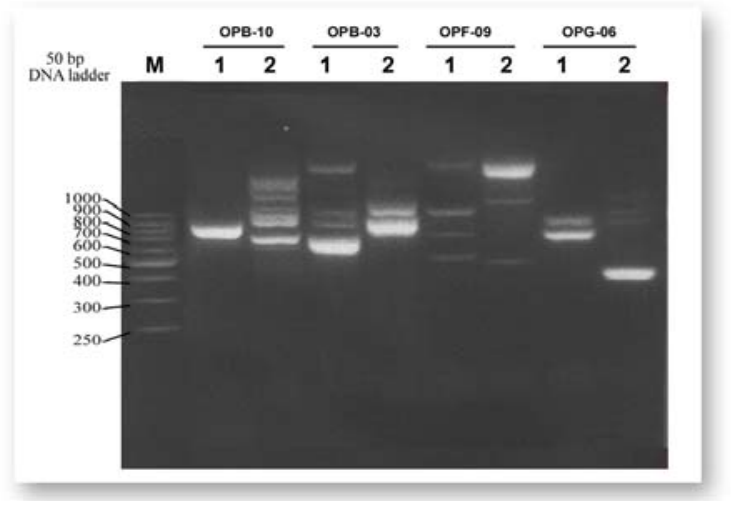

Fig. 3: Agrose - gel electrophoresis of genomic DNA of virgin queens (1) and workers (2) of Camponotus maculatus using RAPD-PCR technique and the primers OPB-10, OPG - 06.

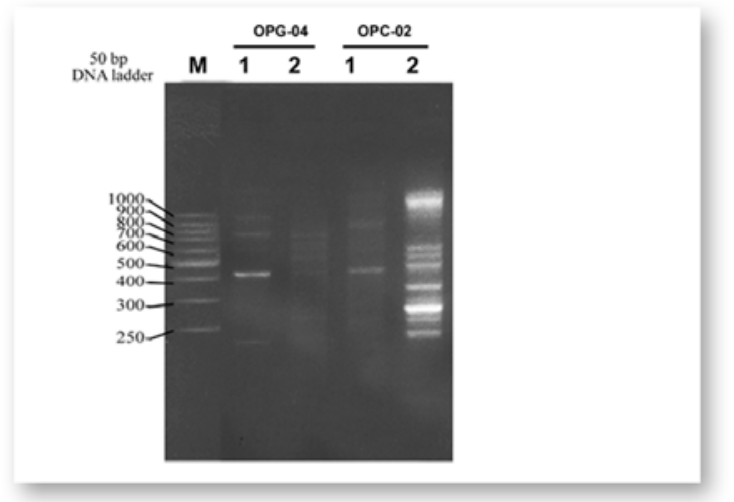

Fig. 4: Agrose - gel electrophoresis of genomic DNA of virgin queens (1) and workers (2) of Camponotus maculatus using RAPD-PCR technique and the primers OPG-04and OPC- 02. 


\section{ARABIC SUMMERY}

الاختلافات البيوكيميائية بين الملكات البكر و الشغالات للنمل (كمبونوتس ماكيو لاتس)

$$
\text { قسم علم الحشر ات ـ كلية العلوم - جامعة عين شمد ـ ـ القاهرة - مصر }
$$

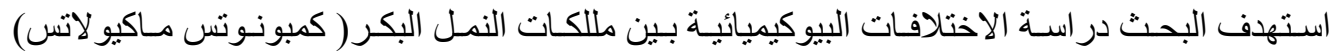

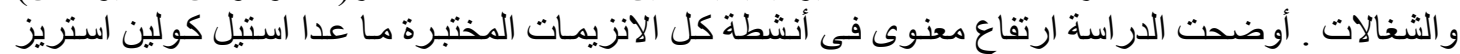

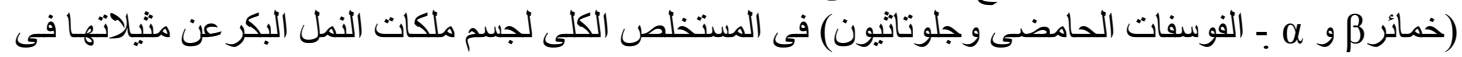

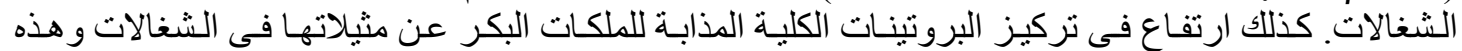

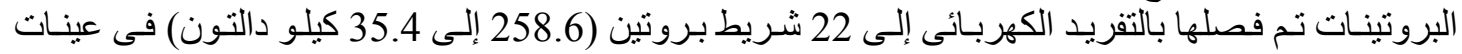

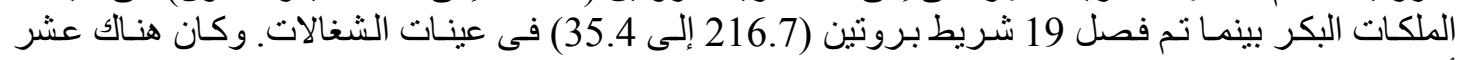

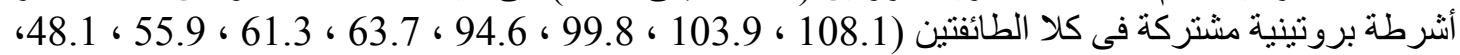
40.6 ، 35.4 كيلو دالتون) وبقية الأشرطة كانت مميزة لكل طائفة و أخير أ كان هناك فرق ، 